\title{
Efficacy Of Cluster Group Model Of Microcredit Delivery For Poverty Reduction In Delta State, Nigeria
}

\author{
${ }^{1}$ Onugu Uchenna C., ${ }^{2}$ Udemadu Chika F \& ${ }^{3}$ Obiekwe J. \\ ${ }^{1 \& 3}$ Department of Agricultural Economics and Extension, Nnamdi Azikiwe University, Awka \\ ${ }^{2}$ Department of Cooperative Economics and Management, Nnamdi Azikiwe University, Awka
}

DOI: 10.29322/IJSRP.11.10.2021.p11877

http://dx.doi.org/10.29322/IJSRP.11.10.2021.p11877

\begin{abstract}
The study on the efficacy of cluster group model of microcredit delivery for poverty reduction in Delta State, Nigeria investigated the socioeconomic profile of the cluster group members, resource profile, and capacity of Delta State microcredit programme (DMCP) to reduce poverty, compare the difference in the poverty index before and after exposure to DMCP, and X-rayed the challenges encountered in the implementation of DMCP. Data were collected with a well-structured questionnaire from a crosssection of 300 cluster group members using a multi-stage random technique. Data were analyzed using a combination of analytical tools such as descriptive statistics, the mean threshold from the 5 Point Likert Scale, and inferential statistics such as t-test. Findings from the study revealed that the majority $(62,67 \%)$ of the cluster group members are female, the mean age, household size, annual income, and farming experience were 40 years, 5 persons, N534,799.60, and 5 years respectively. The resource profile and capacity of the DMCP to reduce poverty in the study area were satisfactory. The study revealed that the mean poverty reduction index before and after DMCP participation were 1.9217 and 3.6433 respectively with a t-value of 7.318 significant at 0.01 probability level. The difference in opinion of DMCP officials and cluster group members on the extent of poverty reduction in Delta State while implementing cluster group model has a t-value of 2.595 significant at 0.05 probability level. Furthermore, the challenges constraining the implementation of DMCP were proximity to microfinance banks/DMCP office, non-sustainability of regular training of clients, the weak numerical strength of cluster group members, among others.
\end{abstract}

Keywords: Microcredit, cluster group, poverty reduction, index, indicators, housing, financial

\section{INTRODUCTION}

The Nigerian government has recognized that for sustainable growth and development, the financial empowerment of the rural areas is vital being the repository of the predominant poor in the society (Okigbo, 2007). Poverty reduction has sometimes been a great concern to many developing nations, Nigeria inclusive. As a result, poverty reduction strategies have been at the center stage of a development programme. Onugu (2007) suggested that poverty is seen as a state of persons who exist with little or no material means of surviving, little or no economic liberation, capital infrastructure, employment, and productivity.

Therefore, Delta State has witnessed social vices among which are child and women labour, kidnapping, oil bunkering, thuggery, killing, armed robbery, and drug addiction mostly among the youths. These lead to widespread poverty that causes illiteracy, lack of educational exposure, technical inadequacy, poor business opportunity, and underemployment (DMCP Journal, 2010). The Delta State government recognized that poverty is a threat to the peace and security of socio-economic development. Therefore, alleviating poverty and driving the socio-economic development at the grass-root is aimed at achieving the State government's three-point agenda on peace and security, human capital, and infrastructural development (DMCP, 2010). This rolled out the Delta State Micro-Credit Programme (DMCP) established to achieve this purpose through the formation of cooperative cluster groups within the communities in the three senatorial districts (Delta North, South, and Central) of Delta State. These groups may be single or multipurpose cooperative by nature with a minimum of ten members to a maximum of twenty-five members. It was important to note that all the members of the group must be involved in the same trade and resident in the local government of origin. Thus, Onugu (2007) thus, 

opined that a lot has been done by both governmental and non-governmental agencies to reduce poverty to its barest minimum because of the dangerous dimension it has assumed over the decades.

Onuoha (2001) further stated that cooperatives are not sponsored to provide only the objectives of their members but also government objectives. The government uses the cooperative movement as an instrument in its effort to promote the livelihood and welfare of its citizens, but a look at the majority of the people reveals widespread misery because their living standard has deteriorated due to low income and hunger. Only a few individuals have access to education, health care services, good road, and adequate shelter (DMCP Journal, 2010). Therefore, DMCP was established and designed to address poverty among Deltans in both rural and urban communities. The scheme was designed as a product for self-help through cluster groups in the 25 local government areas, it was also designed to help grow the culture of microfinance and economic activism that will lead to economic growth. DMCP was equally designed to specifically achieve economic enhancement and independence of the poor. Also targeted at leap-frogging the State into an active commercial territory and genuine desire to reduce drastically unemployment. This study was initiated due to insufficient empirical evidence and documentation on DMCP so far the knowledge of the research can imagine. The study, therefore, explores the dynamics of the cluster group model of DMCP. It compares the poverty index of the beneficiaries of the microcredit delivery as prosecuted by programme before and after its intervention and equally asks whether the opinion of the providers and users of the microcredit differs in the prowess of the cluster model in reducing poverty in Delta State.

\section{Objectives of the study}

The specific objectives of the study were to:

i. examine the socioeconomic profile of the cluster group members involved in DMCP,

ii. assess the resource profile and capacity of DMCP to reduce poverty,

iii. compare the difference in the poverty index (human development, food security, and vulnerability, dwelling, assets, income, education, and savings) of the DMCP members before and after exposure to DMCP cluster groups, and

iv. identify the challenges DMCP encountered in reducing poverty through the cluster group model.

\section{Hypotheses}

$\mathrm{Ho}_{1}$ : there is no significant difference in the rating of the poverty index (human development, food security, and vulnerability, dwelling, asset, income, education, and savings) of DMCP beneficiaries before and after.

$\mathrm{Ho}_{2}$ : there is no significant difference in the opinion of DMCP officials and cluster members on the extent poverty has been reduced in Delta State.

\section{METHODOLOGY}

\section{Study area}

The study was carried out in Delta State, Delta State is one of the states in the South-South geo-political zone of Nigeria. The State has a population of 4,698,391 and a projected population growth rate of $3 \%$ per annum (NPC, 2006). About $80 \%$ of the productive age depends on farming, fishing, hunting, and civil service for their livelihood, while the remaining $20 \%$ are engaged in other service 
sectors such as welding, hairdressing, tailoring, barbing (DMCP, 2010). The State comprises 25 local government areas. The State is located on the latitude of $5^{\circ} .32^{\mathrm{I}} 18^{\mathrm{II}}$ and $5^{\circ} .70^{\mathrm{I}} 40^{\mathrm{II}} \mathrm{N}$ and longitude $5^{\circ} .93^{\mathrm{I}} 39^{\mathrm{II}}$ and $6^{\circ} .12^{\mathrm{I}} 57^{\mathrm{II}}$ E. Delta State equally cover a landmass of $17,698 \mathrm{~km}^{2}$.

A multi-stage sampling technique was adopted by the study. In the first stage, the list of registered cluster groups in Delta State comprising of 21 cluster groups in each of the 3 senatorial zones totaling 1196 members was made available by the officials in charge of DMCP registration in the Delta State Ministry of agriculture. Taro Yamane (1967) sample size determination in Otabor and Obahiagbon (2016) was used to determine the adequate sample size for the study as defined by:

$n=\frac{N}{1+N(e)^{2}}$

Where: $\mathrm{n}=$ sample size, $\mathrm{N}=$ population size, $\mathrm{e}=$ marginal error. Thus;

$n=\frac{1196}{1+1196(0.05)^{2}}$

$n=\frac{1196}{1+1196(0.0025)}$

$n=\frac{1196}{3.99}=299.75(300)$

Also, in the second stage, Kumaison (1997) stratum sample allocation cited in Obianefo, Osuafor, and Ng'ombe (2021) was used to allocate the respective stratum from each senatorial zone as defined by:

ith $=\frac{n i}{N} n$

Where: $i$ th $=$ stratum allocation, $\mathrm{ni}=$ population of each strata, $\mathrm{n}=$ sample size for the study, $\mathrm{N}=$ total population. Thus,

Delta Central: ith $=\frac{394}{1196} * 300=99$

Delta North: ith $=\frac{400}{1196} * 300=100$

Delta South: ith $=\frac{402}{1196} * 300=101$

Table I: Sample representation for the study

\begin{tabular}{|l|l|l|l|}
\hline Sn. & Senatorial Zone & No of beneficiaries & stratum \\
\hline 1 & Delta central & 394 & 99 \\
\hline 2 & Delta North & 400 & 100 \\
\hline 3 & Delta South & 402 & 101 \\
\hline & Total & $\mathbf{1 1 9 6}$ & $\mathbf{3 0 0}$ \\
\hline
\end{tabular}

Source: Researcher's computation, April 2015.

Finally, a well-structured questionnaire and facial interview was the research instrument used to elicit information from a crosssection of 300 beneficiaries randomly selected as reflected from the stratum allocation. 
Data Analysis

Both descriptive and inferential statistics were used to achieve the study objectives using SPSS version 23. The descriptive statistics include simple percentage, frequency table, and men with a threshold of 3.0 from analysis of the 5 points Likert scale, where any variable less than 3.0 was considered negative, while any variable greater than or equal to 3.0 was considered positive which was used to achieve objective 1,3, and 4 . Objective 2 was achieved from the secondary data through documented information as well as a personal interview of DMCP staff. A paired sample t-test was used to validate the null hypothesis one and two.

\section{Model specification}

A). descriptive statistics used to operationalize objective is defined by:

$\bar{X}=\sum \frac{F X}{n}$

Where:

$\overline{\mathrm{X}}=$ sample mean

$\mathrm{X}=$ variable outcome

$\mathrm{F}=$ frequency of occurrence of each variable

$\mathrm{n}=$ sample size

B). the mean threshold from 5 point Likert scale for objective 3 and 4 is defined by:

$\bar{x}=\frac{n(S A+A+S W A+D+S D)}{N}=3.0$

Where:

$\bar{x}=$ mean threshold

$\mathrm{SA}=$ strongly agree

$\mathrm{A}=$ agree

SWA $=$ somewhat agree

$\mathrm{D}=$ disagree

$\mathrm{SD}=$ strongly disagree

$\mathrm{n}=$ number of occurrence

$\mathrm{N}=$ sample size.

Equally, the t-test used for the four hypotheses was defined by:

$$
t=\frac{\bar{X}_{2}-\bar{X}_{1}}{\sqrt{\frac{s_{2}^{2}}{n_{2}}+\frac{s_{1}^{2}}{n_{1}}}}
$$

Where: 
$\bar{X}_{2}=$ mean after joining DMCP

$\bar{X}_{1}=$ mean before joining DMCP

$S_{2}^{2}=$ standard deviation after joining DMCP

$S_{1}^{2}=$ standard deviation before joining DMCP

$\mathrm{n}_{2}=$ sample size after joining DMCP

$\mathrm{n}_{1}=$ sample size before joining DMCP

\section{RESULTS AND DISCUSSIONS}

\section{Summary statistics of DMCP beneficiaries' socioeconomic profile}

Table II reflects the socioeconomic profile of the beneficiaries. The study revealed that the majority $(62,67 \%)$ of the beneficiaries are female, the mean age, household size, annual income, and farming experience were 40 years, 5 persons (4.7), $\$ 534,799.60$, and 5 years (4.8) respectively. Interestingly, a greater proportion $(45.33 \%)$ of the beneficiaries attended secondary and are mainly farmers $(34.67 \%)$.

Table II: Socioeconomic profile of the DMCP beneficiaries $(n=300)$

\begin{tabular}{|c|c|c|c|c|}
\hline Sn. & Members profile & Frequency & Percentage (\%) & Mean \\
\hline \multirow[t]{4}{*}{1} & Age (Years) & & & \\
\hline & $18-30$ & 122 & 40.67 & \\
\hline & $31-50$ & 104 & 34.67 & 40 \\
\hline & 51 and above & 74 & 24.67 & \\
\hline \multirow[t]{3}{*}{2} & Sex & & & \\
\hline & Male & 112 & 37.33 & \\
\hline & Female & 188 & 62.67 & \\
\hline \multirow[t]{5}{*}{3} & Level of education & & & \\
\hline & Primary school & 90 & 30.00 & \\
\hline & Secondary school & 136 & 45.33 & \\
\hline & Degree & 72 & 24.00 & \\
\hline & Post graduate & 2 & 0.67 & \\
\hline \multirow[t]{7}{*}{4} & Primary occupation & & & \\
\hline & Trading & 69 & 23.00 & \\
\hline & Farming & 104 & 34.67 & \\
\hline & Civil servant & 25 & 8.33 & \\
\hline & Artisan & 35 & 11.67 & \\
\hline & Fishing & 57 & 19.00 & \\
\hline & Pensioner & 10 & 3.33 & \\
\hline \multirow[t]{3}{*}{5} & Household size & & & \\
\hline & $1-3$ persons & 106 & 35.33 & \\
\hline & $4-6$ persons & 122 & 40.67 & 4.7 \\
\hline
\end{tabular}


6

$\begin{array}{llr}7-10 \text { persons } & 70 & 23.33 \\ 11 \text { and above } & 2 & 0.67\end{array}$

\section{Annual income (N)}

$\begin{array}{llr}100,000-500,000 & 201 & 67.00 \\ 501,000-1,000,000 & 92 & 30.67 \\ 1,100,000-5,000,000 & 6 & 2.00 \\ 5,100,000 \text { and above } & 1 & 0.33\end{array}$

3.33

(1)
0.33

55.67

$1-5$ years 167

37.33

4.80

6.00

$11-15$ years $\quad 18$

$3 \quad 1.00$

$534,799.60$

16 years and above

Source: Field Survey Data, April 2015.

\section{Resource profile and capacity of DMCP to reduce poverty}

Table III reflects the resource profile and capacity of DMCP to reduce poverty in Delta State, Nigeria. The documented information revealed that DMCP commenced operation in 2008. In the first five years, it consistently had an annual budgetary allocation of five hundred million Naira (N500m). At the end of 2013; it had altogether three billion Naira (N3b) to execute its poverty reduction in Delta State. The study also revealed that $20 \%$ of the annual budget was dedicated to capacity building in form of training and skills acquisition. In specific terms, DMCP partnership with UNIDO has led to the establishment of a shoemaker's village at Issele Uku, Asaba-Benin expressway in Delta State. The goal of the partnership was to provide meaningful employment for thousands of youths and to grow and diversify the economy of Delta State beyond oil vision, also, for poverty reduction through productive activities, trade, capacity building, and environment.

Table III: Resource profile and capacity of DMCP to reduce poverty $(n=20)$

\begin{tabular}{|c|c|c|c|c|c|}
\hline Variables & Frequency & Percentage (\%) & Min. & Max. & Mean \\
\hline Years of establishment & & & 1 & 8 & 5 years \\
\hline Budgetary allocation & & & $\mathrm{N} 500 \mathrm{~m}$ & N100 billion & \\
\hline Staff strength & & & 1 & 50 & 30 \\
\hline Client strength & & & 100 & 10,000 & 1196 \\
\hline No of cluster groups & & & 100 & 5,000 & 10,429 \\
\hline No of clients & & & 1,000 & 10,000 & 1,196 \\
\hline Strength of each group & & & 1 & 100 & 12 \\
\hline \multicolumn{6}{|l|}{ DMCP activities } \\
\hline Training & 12 & 100 & & Effective & 5.0 \\
\hline Skill acquisition & 12 & 100 & & Effective & 5.0 \\
\hline Lending & 10 & 83.3 & & Effective & 4.0 \\
\hline Credit guarantee & 11 & 91.6 & & Effective & 4.8 \\
\hline credit signing & 12 & 100 & & Effective & 5.0 \\
\hline Cluster group formation & 9 & 75 & & Effective & 3.9 \\
\hline Monitoring & 11 & 91.6 & & Effective & 4.8 \\
\hline Performance evaluation & 12 & 100 & & Effective & 5.0 \\
\hline Publicity & 12 & 100 & & Effective & 5.0 \\
\hline \multicolumn{6}{|l|}{ Partnership agencies } \\
\hline UNIDO & 12 & 100 & & Effective & 5.0 \\
\hline GEOSI & 12 & 100 & & Effective & 54.8 \\
\hline Arnamani & 11 & 91.6 & & Effective & 5.0 \\
\hline Modapelle Academy & 12 & 100 & & Effective & 5.0 \\
\hline Clark shoes & 12 & 100 & & Effective & 5.0 \\
\hline
\end{tabular}

This publication is licensed under Creative Commons Attribution CC BY. 


\begin{tabular}{lllll}
\hline Ontario institute & 11 & 91.6 & Effective & 4.8 \\
Oxford university & 10 & 83.3 & Effective & 4.4 \\
University of Toronto & 12 & 100 & Effective & 5.0 \\
\hline
\end{tabular}

Source: Field Survey Data, April 2015.

\section{Poverty index rating establishment of DMCP members}

Five-point Likert scale with standard mean rating 3.0, any index indicator greater than equal to 3.0 is strong and positive while one less than 3.0 is weal or negative was used to analyze the Table on their personal experience before and after joining the cluster groups. The study shows that on human-related indicators which had a grand mean of 2.96 before they joined the group and now having 4.16 after joining the group. Financial assets equally had a grand of 2.54 and 3.94 before and after respectively. Food-related indices had a grand mean of 2.38 and 5.52 before and after joining the group respectively. Dwelling/housing indicators had a grand mean of 2.60 and 2.94 before and after joining the group respectively. Cooking energy sources had a grand mean of 2.76 and 3.07 before and after joining the group respectively. Furthermore, physical assets had a grand mean of 2.82 and 3.33 before and after joining the cluster group respectively. This has shown that DMCP had an effect on the poverty reduction index which was further ascertained with the test of hypotheses.

Table IV: Poverty index rating establishment of DMCP members

\begin{tabular}{|c|c|c|c|c|}
\hline Poverty index indicators & Before & & After & \\
\hline Human development indicators & Mean & Decision & Mean & Decision \\
\hline Vocational skills (farming, cloth making, carpentry) & 3.95 & Established & 4.82 & Establishe \\
\hline Attending conference, seminars and workshops & 2.02 & Not established & 4.16 & Establishe \\
\hline Primary education certificate & 3.61 & Established & 5 & Establishe \\
\hline secondary education certificate & 2.83 & Not established & 4.08 & Establishe \\
\hline Tertiary education (OND, BSc., Postgraduate) certificate & 2.98 & Not established & 3.18 & Establishe \\
\hline Networking activities among group/related business personnel & 2.36 & Not established & 3.72 & Establishe \\
\hline Grand mean & 2.96 & Not established & 4.16 & Establish \\
\hline \multicolumn{5}{|l|}{ Economic (Financial) asset related indicators } \\
\hline Access to personal savings & 2.17 & Not established & 4.01 & Establishe \\
\hline Access to credit & 2.92 & Not established & 4.62 & Establishe \\
\hline Level of personal income & 2.4 & Not established & 3.84 & Establishe \\
\hline Access to insurance & 2.68 & Not established & 3.29 & Establishe \\
\hline Grand mean & 2.54 & Not established & 3.94 & Establish \\
\hline \multicolumn{5}{|l|}{ Food related indicators } \\
\hline Bulk purchase of food stuff & 2.06 & Not established & 4.96 & Establishe \\
\hline Household access to adequate feeding & 2.19 & Not established & 4.21 & Establishe \\
\hline Household access to quality and balanced feeding & 2.83 & Not established & 3.62 & Establishe \\
\hline Household access to good drinking water & 2.45 & Not established & 4.9 & Establishe \\
\hline Grand mean & 2.38 & Not established & 4.52 & Establish \\
\hline \multicolumn{5}{|l|}{ Dwelling/housing indicators } \\
\hline Live in duplex & 2.21 & Not established & 2.98 & Not establ \\
\hline Live in flat & 2.21 & Not established & 4.24 & Establishe \\
\hline Live in concrete house & 2.68 & Not established & 3.1 & Establishe \\
\hline Live in a mud/Thach house & 3.72 & Established & 2.11 & Not establ \\
\hline
\end{tabular}




\begin{tabular}{|c|c|c|c|c|}
\hline Have power generating set & 2.28 & Not established & 4.18 & Establishe \\
\hline Have access to electricity supply & 2.52 & Not established & 3.02 & Establishe \\
\hline Grand mean & 2.60 & Not established & 2.94 & Not estab \\
\hline \multicolumn{5}{|l|}{ Cooking energy source indicator } \\
\hline Make use of wood & 4.08 & Established & 2.08 & Not estal \\
\hline Make use of charcoal & 3.24 & Established & 3.67 & Establis \\
\hline Make use of kerosene stove & 2.19 & Not established & 3.21 & Establis \\
\hline Make use of electric cooker & 2.21 & Not established & 3.76 & Establis \\
\hline Make use of gas cooker & 2.1 & Not established & 2.66 & Not est: \\
\hline Grand mean & 2.76 & Not established & 3.07 & Establish \\
\hline \multicolumn{5}{|l|}{ Physical assets related indicators } \\
\hline Possess bicycle & 4.08 & Established & 3.1 & Establis \\
\hline Possess motorcycle & 2.86 & Not established & 3.62 & Establis \\
\hline Possess tricycle & 2.09 & Not established & 3.48 & Establis \\
\hline Possess canoe & 3.02 & Established & 4.03 & Establis \\
\hline Possess boat & 2.62 & Not established & 2.11 & Not esta \\
\hline Possess car & 2.1 & Not established & 2.18 & Not esta \\
\hline Possess building & 2.93 & Not established & 2.06 & Not esta \\
\hline Possess plot of land & 2.18 & Not established & 2.49 & Not est: \\
\hline Possess electricity generating plant & 2.31 & Not established & 3.66 & Establis \\
\hline Possess colour television & 2.84 & Not established & 4.96 & Establis \\
\hline Possess musical set & 3.98 & Established & 5 & Establishe \\
\hline Grand mean & 2.82 & Not established & 3.33 & Establis \\
\hline
\end{tabular}

Source: Field Survey Data, April 2015.

\section{Effect of DMCP activities on poverty reduction}

To identify the extent of DMCP activities affected poverty reduction status of the beneficiaries as reported by the clients and staff of DMCP was reflected in Table V, five points Likert scale was used to analyze the Table with a mean rating of 3.0; any variable greater than or equal to 3.0 is strong or positive, while variables less than 3.0 is weak or negative. Evidence from the study shows that DMCP had a grand mean of 3.64 and 4.22 for both clients and staff respectively. This is an indication that DMCP empowerment activities positively affected poverty reduction through cluster groups to a great extent. Thus, these empowerment activities include; use economies of scale in business advancement, Delta State government political will and intervention through DMCP, development agencies (UNIDO, USAID, BOI) collaboration and support, promoting development networking among DMCP clients, access to savings mobilization, food security expectations, skill acquisition, and access, value-added access, marketing access, capacity building, access to credit, access to business infrastructure, access to social infrastructure, enhancement of positive self-esteem, empowerment opportunities, and access to clothing and shelter.

Table V: Effect of DMCP activities on poverty reduction

\begin{tabular}{llcccc} 
& & \multicolumn{2}{c}{ DMCP clients } & \multicolumn{2}{c}{ DMCP staff } \\
Sn. & DMCP empowerment variables & mean & Decision & Mean & Decision \\
\hline use economies of scale in business advancement & 3.48 & Great extent & 4.18 & Great extent \\
& $\begin{array}{l}\text { Delta State government political will and intervention through } \\
\text { DMCP }\end{array}$ & 3.06 & Great extent & 4.66 & Great extent \\
\hline
\end{tabular}


Development agencies (UNIDO, USAID, BOI) collaboration and support

Promoting development networking among DMCP clients

\begin{tabular}{|c|c|c|c|}
\hline 4.14 & Great extent & 4.82 & Great extent \\
\hline 3.72 & Great extent & 3.64 & Great extent \\
\hline 4.59 & Great extent & 4.42 & Great extent \\
\hline 3.25 & Great extent & 4.91 & Great extent \\
\hline 4.62 & Great extent & 4.76 & Great extent \\
\hline 3.33 & Great extent & 4.16 & Great extent \\
\hline 3.16 & Great extent & 3.7 & Great extent \\
\hline 3.88 & Great extent & 3.98 & Great extent \\
\hline 3.24 & Great extent & 4.96 & Great extent \\
\hline 4.44 & Great extent & 3.1 & Great extent \\
\hline 3.62 & Great extent & 3.42 & Great extent \\
\hline 3.27 & Great extent & 3.17 & Great extent \\
\hline 3.04 & Great extent & 4.9 & Great extent \\
\hline 3.4 & Great extent & 4.74 & Great extent \\
\hline 3.64 & Great extent & 4.22 & Great extent \\
\hline
\end{tabular}

Access to savings mobilization

Food security expectations (availability and quality)

Skill acquisition and access (hairdressing)

Value added access (processing, packaging of products)

Marketing access (better product sales)

Capacity building (training entrepreneurial support)

Access to credit (loan)

Access to business infrastructure (logistics, power)

Access to social infrastructure (education, health, portable water)

Enhancement of positive self esteem

Empowerment opportunities

Access to clothing and shelter (housing)

3.64

Great extent

4.22 Great extent

Source: Field Survey Data, April 2015.

\section{Challenges of executing cluster group model of poverty reduction}

To identify the challenges encountered by DMCP in reducing poverty through cluster group modeling, a five-point Likert scale rating was used to analyzed the data using a mean threshold of 3.0. Variables greater equal to 3.0 are strong and positive, while variables less than 3.0 are weak and negative. Evidence from the study shows that both the DMCP client and staff had a grand mean of 2.61 and 2.67 respectively, this implies that the challenges identified disagree in the decision as constituting a challenge to the administration of DMCP activities in reducing poverty in Delta State.

Table VI: Challenges of executing cluster group model of poverty reduction

\begin{tabular}{ll} 
Sn. & Possible challenges \\
\hline $\mathrm{i}$ & Poverty state of members \\
\hline & This publication is licensed under Creative Commons Attribution CC BY. \\
http://dx.doi.org/10.29322/IJSRP.11.10.2021.p11877
\end{tabular}

DMCP clients mean Decision 2.28 Disagree
DMCP staff Mean

$3.1 \quad$ Agree 
ii
Loan default

Loan diversion

Poor management of business

Proximity to microfinance bank/DMCP office

Inadequate capital (fund) of beneficiaries

Poor monitoring and supervision of beneficiaries

Lack of credit information

illiteracy among members

Lack of organization among cluster members

Non-sustainability of regular training of beneficiaries

Corruption and embezzlement

Delay in loan approval

Demand for collateral from financial institution (Banks, MFBs)

Weak numerical strength of members

Poor attitude of cluster group members

Unfavourable economic situation

High interest rate demand from bank

Weak leadership of cluster group members

Grand mean

Source: Field Survey Data, April 2015.

\begin{tabular}{clrl}
2.98 & Disagree & 2.12 & Disagree \\
2.11 & Disagree & 2.72 & Disagree \\
2.08 & Disagree & 3.6 & Agree \\
3.72 & Agree & 2.1 & Disagree \\
2.2 & Disagree & 2.18 & Disagree \\
2.84 & Disagree & 2.22 & Disagree \\
2.18 & Disagree & 2.68 & Disagree \\
2.12 & Disagree & 3.7 & Agree \\
2.86 & Disagree & 2.12 & Disagree \\
3 & Agree & 2.92 & Disagree \\
2.17 & Disagree & 2.6 & Disagree \\
2.92 & Disagree & 2.4 & Disagree \\
2.1 & Disagree & 2.9 & Disagree \\
3.68 & Agree & 2.68 & Disagree \\
2.19 & Disagree & 2.13 & Disagree \\
$\mathbf{3 . 6 6}$ & Agree & 3.10 & Agree \\
2.14 & Disagree & 2.8 & Disagree \\
2.29 & Disagree & 2.68 & Disagree \\
$\mathbf{2 . 6 1}$ & Disagree & $\mathbf{2 . 6 7}$ & Disagree \\
\hline
\end{tabular}

\section{Hypotheses testing}

\section{Hypothesis one: Significant difference in rating of the poverty index}

Table VI reflects the significant difference in the poverty index rating before and after DMCP activities in reducing poverty in Delta State while adopting the cluster group model, the study revealed that the mean before and after were 1.9217 and 3.6433 respectively with 5 degrees of freedom (DF). In absolute value; the t-calculated was 7.318 significant at the probability or alpha level of 0.01 , this implies that DMCP had a verifiable impact on the poverty index in the study area, thus, hypothesis one was therefore rejected and the alternative accepted.

Table VI: Paired t-test of the significant difference in rating of the poverty index

\begin{tabular}{llllll}
\hline Poverty index rating & Mean & Std. dev. & DF. & t & Sig. (2 tailed) \\
\hline Before & 1.9217 & 0.25864 & 5 & -7.318 & 0.001 \\
After & 3.6433 & 0.61314 & & & \\
\hline
\end{tabular}

Source: Field Survey Data, April 2015.

Hypothesis two: Significant difference in opinion of DMCP officials and cluster members on the extent of poverty reduction

Table VII reflects the significant difference in opinion of DMCP officials and cluster group members on the extent of poverty reduction in Delta State while implementing cluster group model, the study revealed that the mean of cluster group members and officials were 3.64 and 4.22 respectively with 15 degrees of freedom (DF). In absolute value; the t-calculated was 2.595 significant at 
the probability or alpha level of 0.05 , this implies that the opinions of cluster group members on the extent of poverty reduction while implementing DMCP differs among group users and officials in the study area. Thus, the null hypothesis two was equally rejected, and the alternative accepted

Table VI: Paired t-test of the significant difference in rating of the poverty index

\begin{tabular}{llllll}
\hline Poverty index rating & Mean & Std. dev. & DF. & t & Sig. (2 tailed) \\
\hline Client & 3.64 & 0.5399 & 15 & -2.595 & 0.07 \\
Staff & 4.22 & 0.6485 & & & \\
\hline Source: & & & & &
\end{tabular}

Source: Field Survey Data, April 2015.

\section{CONCLUSION}

The structures, resource profile, and activities of the Delta State model cluster programme (DMCP) were evaluated as the scheme was saddled with poverty reduction programs in the area since 2007. It noted that DMCP has been the comprehensive and most effective programme so far in the area in terms of poverty alleviation programs. The study after screening the activities of DMCP in poverty reduction observed that there was due diligence, monitoring, and evaluation of their clients. Both the structure and delivery pattern of DMCP is functional. It was also gathered that the beneficiaries are to a great extent much better in the poverty index after joining the programme. The resources and capacity of DMCP to reduce poverty in the study are were not in doubt.

It is of great interest to bring to the public notice that despite DMCP ability to reduce poverty in Delta State, some challenges are constraining effectiveness in the implementation of the programme mandate, these challenges include bot not limited to; proximity to microfinance banks/DMCP office, non-sustainability of regular training of clients, the weak numerical strength of cluster group members, among others. Therefore, the study recommends that;

1. There is a need to site microfinance banks and poverty alleviation programme offices closer to the user of the scheme.

2. For programme sustainability, more youth should be targeted.

3. Cluster group members should be properly educated on business management.

\section{REFERENCES}

DMCP (2010). Delta State government to empower more youths. In L. Oji. Retrieved August 20, 2014 from www.vanguard.com/2010/08/dmcp-delta-govt-to-empower-more-youths/amp/?espv=1

Ekwere, G. E. \& I. D. Edem (2014). Evaluation of Agricultural Credit Facility in Agricultural Production and Rural Development. Global Journal of Human Social Science. Vol. 14(3), 18-26.

Nigeria Population Commission (NPC) (2006). National Population Census results. Federal Government of Nigeria Official Gazette 24, (94): 6-7.

Obianefo, Osuafor OO and Ng'ombe JN (2020). On the Challenges Faced by Female Members of Agricultural Cooperatives in Southeast Nigeria. Journal of Agricultural Extension and Rural Development, 13(1): 94-106.

Okigbo C. (2007). Postcolonial market of memories. Research in African Literature, 38(4): 70 - 86. DOI: 10.1353/ral.2007.0076 
Onugu C.U. (2007). Credit mobilization challenges of agricultural cooperative society in Anambra State. Journal of Cooperative Economics and Management, 1(1): $94-99$.

Onuoha (2001). Principles of cooperatives. Computer Edge, Enugu.

Otabor J.O. \& Obahiagbon K. (2016). Statistical approach to the link between internal service quality and employee job satisfaction: A Case Study. American Journal of Applied Mathematics and Statistics. 4(6), 178-184. DOI: 10.12691/ajams-4-6-3.

Ugwu A.N. (2013). Conflict management for sustainable development in Nigeria in the $21^{\text {st }}$ century. In B.A Eheazu, C.N Barikor \& I.S. Nzeneri (Eds). Reading in adult and non-formal education. Port Harcourt. University of Port Harcourt Press. (1), 199 211.

Yamane T. (1967). Statistics: An introductory analysis, $2^{\text {nd }}$ edition, New York: Harper and Row. 